\title{
KEMAJUAN TEKNOLOGI PENGINDERAAN JAUH SERTA APLIKASINYA DIBIDANG BENCANA ALAM
}

\author{
Oleh: Lili Somantri*)
}

\begin{abstract}
Abstrak
Indonesia merupakan negara yang besar dengan luas wilayah hampir 2 juta $\mathrm{km}^{2}$ yang terdiri atas 17.480 pulau yang membentang dari barat ke timur. Luas wilayah ini memiliki potensi sumber daya alam yang besar, baik di daratan maupun di laut sebagai modal dalam pembangunan. Akan tetapi Indonesia juga merupakan negara yang rawan bencana baik bencana geologi seperti letusan gunungapi, gempa bumi, dan tsunami, maupun bencana meteorologi seperti banjir, tanah longsor, kekeringan. Oleh karena itu, dalam pembangunan wilayah di Indonesia harus memperhatikan kondisi lingkungannya yang rawan bencana. Bencana alam merupakan peristiwa yang membuat kerugian, baik nyawa maupun harta benda. Kajian bencana alam memerlukan tingkat kerincian data dalam pemetaannya. Data dari penginderaan jauh dapat menyajikan informasi yang rinci sesuai dengan kemampuan resolusi dari citra penginderaan jauh. Kelebihan dari data penginderaan jauh, yaitu dapat mencakup wilayah yang luas karena diambil dari udara, diperoleh dengan cepat dan akurat meskipun daerahnya sulit dijangkau secara survei terestrial sehingga dalam perolehan datanya dapat menghemat biaya, waktu, dan tenaga. Dalam makalah ini akan diuraikan mengenai kemajuan teknologi penginderaan jauh dan aplikasinya untuk kajian bencana alam.
\end{abstract}

Kata kunci : teknologi penginderaan jauh, bencana alam, mitigasi bencana alam

*) Lili Somantri, S.Pd., M.Si., adalah dosen Jurusan Pendidikan Geografi FPIPS UPI

\section{Pendahuluan}

Indonesia merupakan negara yang rawan bencana alam, karena dipengaruhi oleh kondisi geografis dan kondisi geologisnya. Kondisi geografis Indonesia terletak pada daerah khatulistiwa yang diapit oleh posisi silang antara dua benua (Asia, Australia) dan dua samudera (Pasifik, Hindia) dengan penyinaran matahari sepanjang tahun, curah hujan yang tinggi, yang menyebabkan adanya dua musim, yaitu musim hujan dan musim kemarau. Kondisi geologi Indonesia yang terletak pada tiga pertemuan lempeng bumi, yaitu Lempeng Samudera Hindia di selatan, Lempeng Samudera Pasifik di timur, dan Lempeng Benua Eurasia di utara. Berdasarkan posisi ini hampir seluruh wilayah Indonesia rawan bencana geologi, kecuali Pulau Kalimantan, tetapi Pulau Kalimantan rawan bencana meteorologi (banjir, kekeringan, dan kebakaran hutan).

Di era otonomi daerah dan pembangunan, data penginderaan jauh sangat diperlukan untuk inventarisasi dan evaluasi potensi sumber daya alamnya sehingga eksploitasi sumber daya alamnya dapat dilakukan secara besar-besaran 
untuk kemakmuran rakyat tanpa harus mengganggu keseimbangan lingkungan. Akibat dari eksploitasi sumber daya yang berlebihan akan menimbulkan berbagai bencana, misalnya akibat pembalakan hutan menyebabkan banjir karena lahan tersebut tidak dapat menampung air hujan. Kemudian adanya kebakaran hutan sehingga menimbulkan pencemaran asap sampai ke negara tetangga sehingga menimbulkan berbagai penyakit seperti inpeksi saluran pernapasan atas (ISPA) dan terganggunya kegiatan transportasi udara. Oleh karena itu, diperlukan teknologi penginderaan jauh untuk mitigasi bencana alam tersebut.

Teknologi penginderaan jauh dapat menghasilkan data tentang permukaan bumi yang cepat, efisien, efektif, dan lengkap yang sesuai dengan tingkat pengambilan keputusan, baik di tingkat nasional, provinsi, kabupaten/kota bahkan kecamatan. Selain itu, kelebihan dari data penginderaan jauh adalah kesalahan manusia (human error) lebih kecil dan datanya selalu up to date tergantung resolusi temporal dari citra tersebut yang semakin pendek. Untuk melengkapi data penginderaan jauh dapat diintegrasikan dengan survei lapangan sehingga datanya benar-benar akurat yang dijadikan dasar dalam pengambilan keputusan.

Saat ini perkembangan penginderaan jauh sangat cepat dilihat dari kemampuan resolusinya, baik resolusi spasial maupun resolusi temporalnya. Resolusi spasial menyangkut luasan objek yang direkam oleh sensor satelit, misalnya satelit Landsat ketelitian objek yang direkam adalah 30 meter, satelit Quickbird 0,6 meter, dan satelit Ikonos 1 meter. Kemudian resolusi temporalnya semakin cepat, misalnya Landsat 16 hari, satelit Quickbird dan Ikonos 3 hari sehingga dapat mempercepat survei dan pemetaan informasi tentang kebumian. Dengan perkembangan resolusi ini maka untuk kajian bencana alam akan semakin detail.

Perkembangan satelit ini tidak hanya terjadi di negara maju seperti Amerika Serikat (Landsat), Perancis (SPOT), Jepang (JERS), maupun berkembang di negara-negara berkembang seperti India (IRS, Cartosat), Thailand (Theos), Malaysia (Razaksat), maupun Indonesia (Tubsat).

\section{Karakteristik Citra Satelit}

\section{a. Landsat}

Satelit Landsat pertama kali diluncurkan oleh NASA Amerika Serikat pada tahun 1972. Landsat merupakan satelit sumber daya kebumian yang pertama. Pada awalnya citra landsat bernama ERTS (Earth Resources Technology Satellite). Pada ERTS-1 sensor yang digunakan adalah MSS (multispektral scanner) dengan resolusi spasial 80 meter dan RBV (return beam vidcom) dengan resolusi spasial 60 meter. Pada tahun 1975 nama ERTS dirubah menjadi Landsat untuk membedakan dengan Seasat (satelit sumberdaya laut).

Perkembangan selanjutnya pada tahun 1982 dimana diluncurkan Landsat 5 dengan membawa sensor TM (Thematic Mapper). Kemudian April 1999 diluncurkan Landsat-7 dengan membawa sensor ETM+ (Enhanced Thematic Mapper + scanner).

Sensor MSS merupakan suatu alat scanning mekanik yang merekam data dengan cara men-scanning permukaan bumi dalam jalur atau baris tertentu. Kemudian sensor RBV merupakan alat menyerupai televisi yang mengambil citra 
"snapshot" dari permukaan bumi sepanjang track lapangan satelit pada setiap selang waktu tertentu. Sensor TM merupakan alat scan mekanis yang mempunyai resolusi spektral, resolusi spasial, dan resolusi radiometrik (Jaya, 2002 dalam Thoha, 2008).

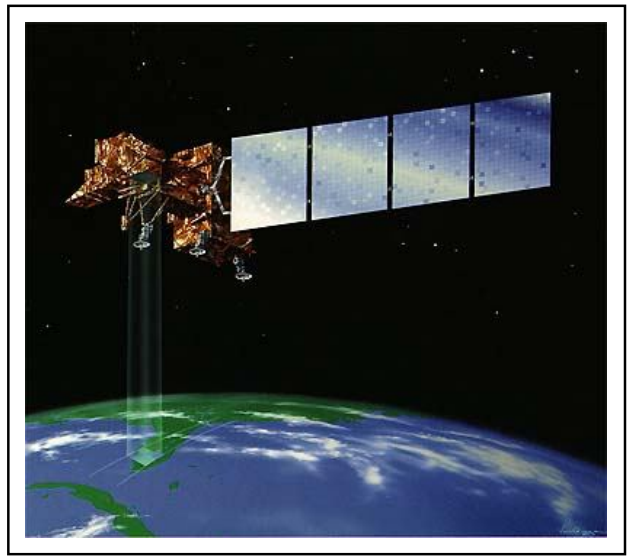

Gambar 1. Satelit Landsat (sumber: http://www.satimagingcorp.com/satellite-sensors/landsat.html diakses pada 24 Februari 2010).

Perkembangan satelit Landsat dapat dilihat pada tabel 1 berikut.

Tabel 1: Perkembangan Satelit Landsat

\begin{tabular}{|c|c|c|c|c|}
\hline "NO & $\begin{array}{c}\text { WAKTU } \\
\text { PELUNCURAN }\end{array}$ & $\begin{array}{c}\text { NAMA } \\
\text { SATELIT }\end{array}$ & "SENSOR & KETERANGAN \\
\hline 1 & 23 Juli 1972-1978 & $\begin{array}{l}\text { ERTS-1 } \\
\text { (Landsat-1) }\end{array}$ & $\begin{array}{l}\text { MSS dan } \\
\text { RBV }\end{array}$ & $\begin{array}{l}\text { Dapat digunakan untuk } \\
\text { skala 1: } 250.000 \\
\text { (pemetaan SDA provinsi) }\end{array}$ \\
\hline 2 & 22 Januari 1975-1981 & $\begin{array}{l}\text { ERTS-2 } \\
\text { (Landsat-2) }\end{array}$ & & \\
\hline 3 & 5 Maret 1978-1983 & Landsat-3 & & \\
\hline 4 & 16 Juli 1982-1993 & Landsat-4 & & $\begin{array}{l}\text { Dioperasikan oleh } \\
\text { EOSAT }\end{array}$ \\
\hline 5 & 1 Maret 1984 & Landsat-5 & $\mathrm{TM}$ & $\begin{array}{l}\text { Dioperasikan oleh } \\
\text { EOSAT }\end{array}$ \\
\hline 6 & 5 Oktober 1993 & Landsat-6 & & Gagal orbit \\
\hline 7 & 15 April 1999 & Landsat-7 & $\begin{array}{l}\text { ETM+sca } \\
\text { nner }\end{array}$ & Dikontrol oleh USGS \\
\hline
\end{tabular}

Sumber : http://id.wikipedia.org/wiki/Program Landsat diakses tanggal 19 Februari 2010.

Satelit Landsat yang saat ini masih beroperasi adalah landsat-5 dengan sensor multispektral scanner (MSS) dan TM (Thematik Mapper).

Tabel 2: Karakteristik Landsat-5

\begin{tabular}{||l|l|l||}
\hline \hline NO & \multicolumn{1}{|c||}{$\begin{array}{c}\text { KARAKTERISTIK } \\
\text { LANDSAT-5 }\end{array}$} & \multicolumn{1}{c|}{ KETERANGAN } \\
\hline 1 & Sensor & $\begin{array}{l}\text { MSS (multispectral scanner) } \\
\text { TM (Thematic Mapper) }\end{array}$ \\
\hline 2 & Resolusi Spektral & Band 1 Biru $(0,45-0,52 \mu \mathrm{m})$ \\
\hline
\end{tabular}




\begin{tabular}{|c|c|c|}
\hline & & $\begin{array}{l}\text { Band } 2 \text { Hijau }(0,52-0,60 \mu \mathrm{m}) \\
\text { Band } 3 \text { Merah }(0,63-0,69 \mu \mathrm{m}) \\
\text { Band } 4 \text { Inframerah Dekat }(0,76-0,90 \mu \mathrm{m}) \\
\text { Band } 5 \text { Inframerah Sedang }(1,55-1,75 \mu \mathrm{m}) \\
\text { Band } 6 \text { Inframerah Thermal }(10,4-12,5 \mu \mathrm{m}) \\
\text { Band } 7 \text { Inframerah Sedang }(2,08-2,35 \mu \mathrm{m})\end{array}$ \\
\hline 3 & Resolusi Spasial & $\begin{array}{l}\text { Band 1,2,3,4,5,7 (30 meter), } \\
\text { Band thermal:120 meter }\end{array}$ \\
\hline 4 & Resolusi Temporal & 16 hari \\
\hline 5 & Luas Liputan & $175 \times 185 \mathrm{~km}$ \\
\hline 6 & Ketinggian Orbit & $705 \mathrm{~km}$ \\
\hline
\end{tabular}

Sumber : Dari berbagai sumber, 2010.

Sensor MSS merupakan sensor optic yang didesain untuk mengobservasi radiasi matahari yang dipantulkan dari permukaan bumi dalam 4 perbedaan band spektral. Sensor TM merupakan versi yang lebih tinggi yang digunakan untuk mengobservasi permukaan bumi dengan 7 band spectral dari tampak sampai inframerah thermal. Berikut data karakteristik Lansat-5.

Banyak sekali aplikasi dari citra landsat TM ini untuk kajian kebumian, seperti untuk pemetaan penggunaan lahan dan penutup lahan (landuse/landcover), kehutanan, pemetaan geologi dan tanah, evaluasi dan manajemen sumber daya lahan, bencana alam, hidrologi dan oseanografi. Lansat merupakan satelit non meteorologi yang memiliki band thermal sehingga dapat digunakan untuk mengukur suhu permukaaan.

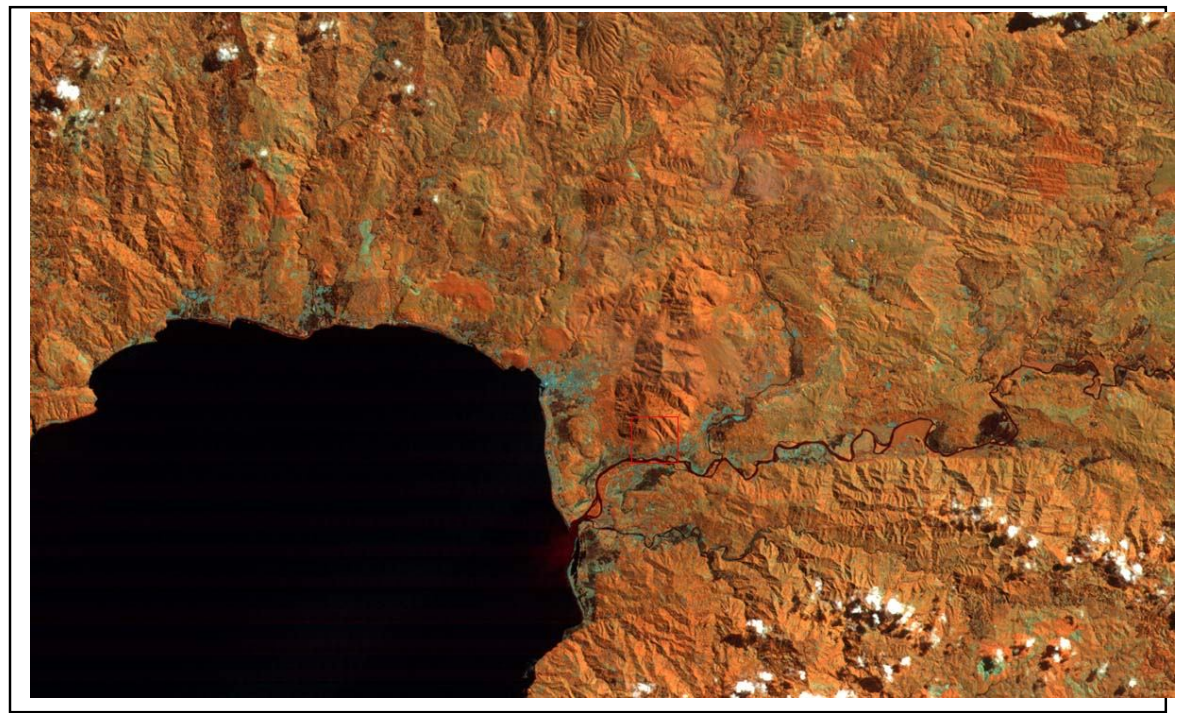

Gambar 2. Citra Lansat TM daerah Palabuhanratu Sukabumi Jawa Barat tahun 2002 yang menggambarkan struktur geologi.

Selain Landsat-5, satelit yang masih beroperasi saat ini adalah Landsat-7 yang dikontrol oleh USGS. Sensor yang digunakan pada Lansat-7 adalah ETM+scanner. Landsat-7 memiliki band thermal yang dipertajan yaitu band 61 
dan band 62. Band-band ETM+ berguna untuk mengkaji air, pemilihan jenis vegetasi, pengukuran kelembaban tanah dan tanaman, pembedaan awan, salju, dan es, serta mengidentifikasi jenis batuan. Band-band yang terdapat pada sensor ETM+ mempunyai kemampuan dan karakteristik yang berbeda-beda dalam menangkap gelombang elektromagnetik dan dipancarkan oleh obyek di permukaan bumi. Karena memiliki resolusi spectral yang tinggi sehingga lebih memudahkan dalam mengidentifikasi objek secara digital. (http://salamspasial.blogspot.com/2008/05/sistem-satelit-landsat-7-etm). Berikut data karakteristik Satelit Lansat-7.

Tabel 3: Karakteristik Satelit Landsat-7

\begin{tabular}{||l|l|l||}
\hline \hline NO & \multicolumn{1}{|c||}{$\begin{array}{c}\text { KARAKTERISTIK } \\
\text { LANDSAT-7 }\end{array}$} & \multicolumn{1}{c||}{ KETERANGAN } \\
\hline 1 & Sensor & ETM+ (Enhanced Thematic Mapper) \\
\hline 2 & Resolusi Spektral & Band 1 biru $(0,450-0,515 \mu \mathrm{m})$ \\
& & Band 2 hijau $(0,525-0,605 \mu \mathrm{m})$ \\
& & Band 3 merah $(0,630-0,690 \mu \mathrm{m})$ \\
& & Band 4 inframerah dekat/NIR $(0,750-0,900 \mu \mathrm{m})$ \\
& & Band 5 gelombang inframerah pendek/SWIR $(1,550-1,750 \mu \mathrm{m})$ \\
& & Band 6 gelombang inframerah thermal/TIR $(10,40-12,50 \mu \mathrm{m})$ \\
& & Band 7 short wave IR $(2,090-2,350 \mu \mathrm{m})$ \\
\hline 3 & Resolusi Spasial & Pankromatik : 15 meter \\
& & Multispektral : 30 meter \\
\hline 4 & Resolusi Temporal & 16 hari \\
\hline 5 & Resolusi Radiometrik & 8 bit $(256$ angka) \\
\hline 6 & Luas Liputan & $185 \mathrm{x} \mathrm{185 \textrm {km }}$ \\
\hline 7 & Ketinggian Orbit & $705 \mathrm{~km}$ \\
\hline \hline
\end{tabular}

Sumber : Dari berbagai sumber, 2010.

Misi Landsat-7 adalah menyajikan data penginderaan Jauh berkualitas tinggi dan tepat waktu dari kanal tampak (visible) dan infra merah yang meliput seluruh daratan dan kawasan di sekitar pantai di permukaan bumi dan secara berkesinambungan. Namun setelah beroperasi lebih dari empat tahun, satelit ini mengalami kerusakan pada bagian SLC (Scan Line Collector) sehingga menghasilkan citra satelit yang tidak utuh, yaitu stripping (garis-garis kosong), USGS telah berusaha memperbaiki kerusakan yang terjadi, tetapi tidak berhasil, bahkan sejak November 2003 kerusakan yang terjadi dinyatakan sebagai kerusakan yang permanen. (Arief, H. 2004).

\section{b. Ikonos}

Satelit Ikonos diluncurkan di Vandenberg, California pada tanggal 24 September 1999 oleh Space Imaging, sebagai fase baru dari perkembangan teknologi satelit komersial yang beresolusi spasial sangat tinggi. Sebelumnya telah diluncurkan ikonos 1 tetapi gagal diluncurkan. Satelit ini dirancang untuk beroperasi selama 7 tahun, mengorbit pada ketinggian 681 kilometer dari permukaan bumi, orbit sun-synchronous dengan sudut inklinasi sebesar $98,2^{\circ}$ dengan lebar sapuan 11 kilometer. 
Satelit Ikonos yang tergolong jenis polar sinkronous matahari ini beredar mengelilingi Bumi di ketinggian 364 mil, 14 kali sehari. Kepekaan kamera pankromatiknya mampu memotret segala macam objek di Bumi hingga yang berdiameter satu meter sekalipun, sedangkan sensor multispektralnya peka pada objek hingga yang berukuran 3,28 meter. Kepekaannya ini didapat karena Ikonos memiliki teleskop optis khusus.

Pemanfaatan citra Ikonos yang menyajikan gambaran sebagaimana aslinya, dengan citra resolusi temporal dan resolusi spasial yang tinggi ini dapat dimanfaatkan untuk membantu upaya pemerintah dalam menangani masalah bencana alam, yaitu memungkinkan untuk menghitung jumlah bangunan yang rusak akibat gempa bumi. Kemudian dapat digunakan untuk melihat perubahan penggunaan lahan dan pemanfaatan lahan terutama untuk kajian yang memerlukan tingkat kedetailan yang tinggi. Data ikonos juga dapat digunakan untuk pemetaan topografi dari skala kecil hingga menengah, tidak hanya menghasilkan peta baru, tetapi juga memperbaharui peta topografi yang sudah ada. (Thoha, 2008).

Tabel 6: Spesifikasi Citra Ikonos

\begin{tabular}{||l|l|l||}
\hline \hline NO & \multicolumn{1}{|c||}{$\begin{array}{c}\text { KARAKTERISTIK } \\
\text { IKONOS }\end{array}$} & \multicolumn{1}{c||}{ KETERANGAN } \\
\hline 1 & Sensor & OSA (optical sensor assembly \\
\hline 2 & Resolusi spektral & $\begin{array}{l}\text { Band } 1(0,45-0,52 \mu \mathrm{m}) \\
\text { Band 2 }(0,52-0,60 \mu \mathrm{m}) \\
\text { Band } 3(0,63-0,69 \mu \mathrm{m}) \\
\text { Band } 4(0,76-0,90 \mu \mathrm{m}) \\
\text { Pankromatik }(0,45-0,90 \mu \mathrm{m})\end{array}$ \\
& & $\begin{array}{l}\text { Pankromatik (hitam putih) }: 1 \text { meter } \\
\text { Multispektral (R,G,B, NIR) }: 4 \text { meter }\end{array}$ \\
\hline 3 & Resolusi spasial & $1-3$ hari \\
\hline 4 & Resolusi temporal & 11 bit \\
\hline 5 & Resolusi radiometrik & $11 \mathrm{~km}$ \\
\hline 6 & Luas Liputan & $680 \mathrm{~km}$ \\
\hline 7 & Ketinggian Orbit & \\
\hline
\end{tabular}

Sumber : dari berbagai sumber, 2010

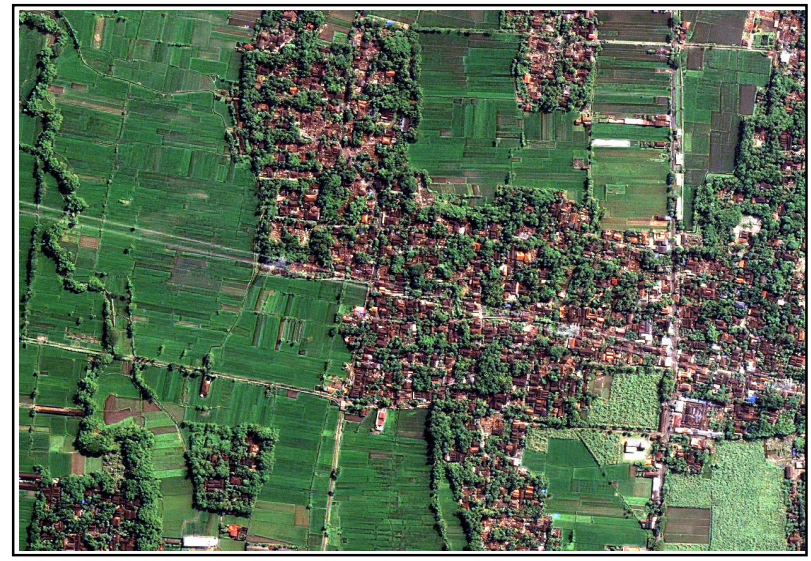

Gambar 3. Citra Ikonos daerah Bantul DIY setelah terjadi gempa bumi 


\section{Aplikasi Penginderaan Jauh untuk Mitigasi Bencana Alam}

Indonesia merupakan negara yang rawan bencana alam, karena dipengaruhi oleh kondisi geografis dan kondisi geologisnya. Kondisi geografis Indonesia terletak pada daerah khatulistiwa yang diapit oleh posisi silang antara dua benua (Asia, Australia) dan dua samudera (Pasifik, Hindia) dengan penyinaran matahari sepanjang tahun, curah hujan yang tinggi, yang menyebabkan adanya dua musim, yaitu musim hujan dan musim kemarau. Kondisi geologi Indonesia yang terletak pada tiga pertemuan lempeng bumi, yaitu Lempeng Samudera Hindia di selatan, Lempeng Samudera Pasifik di timur, dan Lempeng Benua Eurasia di utara. Berdasarkan posisi ini hampir seluruh wilayah Indonesia rawan bencana geologi, kecuali Pulau Kalimantan, tetapi Pulau Kalimantan rawan bencana meteorologi (banjir, kekeringan, dan kebakaran hutan).

Bencana alam dibedakan atas bencana alam geologi dan bencana alam meteorologi. Bencana alam geologi merupakan bencana alam yang disebabkan oleh aktivitas pergerakan tektonik lempeng, yang meliputi letusan gunungapi, gempa bumi, dan tsunami. Bencana alam meterologi merupakan bencana alam yang dipengaruhi oleh kondisi cuaca seperti curah hujan, yaitu banjir, longsor, kekeringan, atau kebakaran hutan.

Bencana alam ini tidak hanya dapat menyebabkan kerugian, baik material (harta benda), moril maupun nyawa yang tidak sedikit sehingga perlu diantisipasi sedini mungkin. Bencana ini tidak mungkin dapat dihindari, yang hanya bisa dilakukan adalah bagaimana mengantisipasi jika terjadi bencana dan meminimalkan kerugian dan korban jiwa. Banyaknya korban jiwa akibat bencana alam karena kurangnya pemahaman masyarakat atau pemerintah setempat mengenai daerah-daerah yang rawan bencana. Oleh karena itu, perlu adanya manajemen bencana. Manajemen bencana ini meliputi kegiatan perencanaan dan penanggulangan bencana, yang dilakukan pada sebelum, saat, dan sesudah terjadi bencana. Manajemen ini bertujuan mencegah korban jiwa, mengurangi kerugian harta benda dan kerusakan infrastruktur.

Mitigasi bencana dilakukan sebelum terjadinya bencana, yang bertujuan untuk meminimalkan dampak dari bencana tersebut. Mitigasi ini dapat berupa menghindari daerah yang rawan bencana sehingga diperlukan informasi mengenai daerah-daerah yang rawan bencana. Informasi ini dalam bentuk peta-peta potensi rawan bencana yang meliputi karakteristik sumber bencana, kemungkinan terjadinya bencana, dan data bencana yang terjadi pada masa lalu.

Teknologi penginderaan jauh digunakan dalam menyediakan data dan informasi mengenai daerah yang rawan bencana alam tersebut. Selain digunakan dalam pemetaan potensi bahaya dari bencana alam, data yang diperoleh dari penginderaan jauh digunakan juga dalam mitigasi bencana seperti dalam pewilayahan zona evakuasi, dan penanganan korban bencana. Mitigasi ini bertujuan untuk menekan dampak negatif dari adanya suatu bencana. Mitigasi bencana alam harus dilakukan dengan cepat,tepat, sehingga sangat memerlukan data dan informasi tentang potensi bencana alam tersebut. Jika harus dilakukan survei lapangan akan memerlukan biaya, waktu dan tenaga, padahal untuk mitigasi bencana perlu data yang cepat sehingga penginderaan jauh merupakan yang paling cocok. 
Jika potensi daerah rawan bencana sudah dapat teridentifikasi dengan baik maka upaya penanggulangannya dapat dilakukan sedini mungkin sehingga kerugiannya dapat ditekan semaksimal mungkin. Dengan diperolehnya peta daerah yang berpotensi bencana alam, dapat disusun penyusunan sistem kewaspadaan dini bencana (early warning system). Peringatan dini ini dilakukan setelah mengetahui informasi daerah yang rawan bencana kemudian informasi ini disebarluaskan kepada masyarakat. Sistem peringatan dini ini harus dilakukan dengan cepat, tepat dan dapat dipercaya.

Dalam kajian bencana alam, data penginderaan jauh juga dapat digunakan untuk monitoring bencana alam, sebelum terjadi bencana dan sesudah terjadi bencana, misalnya untuk mengetahui kerusakan dan mengestimasi kerugian akibat bencana tersebut. Misalnya penggunaan citra ikonos dan quickbird untuk mengetahui besarnya kerusakan akibat gempa dan tsunami di Aceh, gempa bumi Yogyakarta, maupun gempa bumi Padang.

Data dari citra penginderaan jauh digunakan sebagai data penggunaan lahan yang sangat akurat misalnya kerusakan hutan di daerah hulu, perubahan penggunaan lahan sehingga dapat menyebabkan bencana longsor. Untuk kajian bencana longsor dapat dikaji dengan menggunakan citra yang multitemporal. Sehingga dapat diketahui perkembangan atau perubahan penggunaan lahan. kemudian apabila ingin melihat yang potensi longsor selain menggunakan citra landsat yang lebih mengutamakan pantulan suatu objek kemudian digabungkan dengan citra radar yang lebih mengutamakan kekasaran atau topografinya sehingga dapat diketahui penggunaan lahan pada topografi tertentu yang menyebabkan longsor.

Kemudian dengan penginderaan jauh dapat dilihat daerah-daerah permukiman atau lahan yang terkena dapat letusan gunungapi, seperti lahar dan awan panas. Wilayah yang kebakaran hutan. monitoring kerusakan hutan yang selama ini sangat sulit jika dilakukan dengan survei terestris, begitupula mengetahui titik-titik api pada waktu kebakaran hutan).

Oleh karena itu, kajian bencana alam memerlukan data dan informasi yang rinci sesuai dengan keperluan. Untuk mengetahui daerah yang berpotensi bencana alam dalam skala yang semi detail dapat menggunakan data Landsat (30 meter) atau SPOT (20 meter). Data ini dapat digunakan pada level provinsi maupun kabupaten. Akan tetapi jika ingin mengetahui data yang sangat detail seperti mengestimasi kerusakan bangunan akibat bencana dapat menggunakan data Ikonos ( 1 meter) dan quickbird (0,6 meter). Data ini dapat digunakan pada level local misalnya bagian suatu kota dan kecamatan.

Saat ini perkembangan penginderaan jauh sangat cepat dilihat dari kemampuan resolusinya, baik resolusi spasial maupun resolusi temporalnya. Resolusi spasial menyangkut luasan objek yang direkam oleh sensor satelit, misalnya satelit Landsat ketelitian objek yang direkam adalah 30 meter, satelit Quickbird 0,6 meter, dan satelit Ikonos 1 meter. Kemudian resolusi temporalnya semakin cepat, misalnya Landsat 16 hari, satelit Quickbird dan Ikonos 3 hari sehingga dapat mempercepat survei dan pemetaan informasi tentang kebumian. Dengan perkembangan resolusi maka untuk kajian pemetaan sumber daya, data untuk pembangunan, dan kajian bencana alam akan semakin detail. 
Teknologi penginderaan jauh digunakan dalam menyediakan data dan informasi mengenai daerah yang rawan bencana alam tersebut. Selain digunakan dalam pemetaan potensi bahaya dari bencana alam, data yang diperoleh dari penginderaan jauh digunakan juga dalam mitigasi bencana seperti dalam pewilayahan zona evakuasi, dan penanganan korban bencana. Mitigasi ini bertujuan untuk menekan dampak negatif dari adanya suatu bencana. Mitigasi bencana alam harus dilakukan dengan cepat,tepat, sehingga sangat memerlukan data dan informasi tentang potensi bencana alam tersebut. Jika harus dilakukan survei lapangan akan memerlukan biaya, waktu dan tenaga, padahal untuk mitigasi bencana perlu data yang cepat sehingga penginderaan jauh merupakan yang paling cocok.

Jika potensi daerah rawan bencana sudah dapat teridentifikasi dengan baik maka upaya penanggulangannya dapat dilakukan sedini mungkin sehingga kerugiannya dapat ditekan semaksimal mungkin. Dengan diperolehnya peta daerah yang berpotensi bencana alam, dapat disusun penyusunan sistem kewaspadaan dini bencana (early warning system). Peringatan dini ini dilakukan setelah mengetahui informasi daerah yang rawan bencana kemudian informasi ini disebarluaskan kepada masyarakat. Sistem peringatan dini ini harus dilakukan dengan cepat, tepat dan dapat dipercaya.

Dalam kajian bencana alam, data penginderaan jauh juga dapat digunakan untuk monitoring bencana alam, sebelum terjadi bencana dan sesudah terjadi bencana, misalnya untuk mengetahui kerusakan dan mengestimasi kerugian akibat bencana tersebut. Misalnya penggunaan citra ikonos dan quickbird untuk mengetahui besarnya kerusakan akibat gempa dan tsunami di Aceh, gempa bumi Yogyakarta, maupun gempa bumi Padang.

Data dari citra penginderaan jauh digunakan sebagai data penggunaan lahan yang sangat akurat misalnya kerusakan hutan di daerah hulu, perubahan penggunaan lahan sehingga dapat menyebabkan bencana longsor. Untuk kajian bencana longsor dapat dikaji dengan menggunakan citra yang multitemporal. Sehingga dapat diketahui perkembangan atau perubahan penggunaan lahan. kemudian apabila ingin melihat yang potensi longsor selain menggunakan citra landsat yang lebih mengutamakan pantulan suatu objek kemudian digabungkan dengan citra radar yang lebih mengutamakan kekasaran atau topografinya sehingga dapat diketahui penggunaan lahan pada topografi tertentu yang menyebabkan longsor.

Kemudian dengan penginderaan jauh dapat dilihat daerah-daerah permukiman atau lahan yang terkena dapat letusan gunungapi, seperti lahar dan awan panas. Wilayah yang kebakaran hutan. monitoring kerusakan hutan yang selama ini sangat sulit jika dilakukan dengan survei terestris, begitupula mengetahui titik-titik api pada waktu kebakaran hutan).

Oleh karena itu, kajian bencana alam memerlukan data dan informasi yang rinci sesuai dengan keperluan. Untuk mengetahui daerah yang berpotensi bencana alam dalam skala yang semi detail dapat menggunakan data Landsat (30 meter) atau SPOT (20 meter). Data ini dapat digunakan pada level provinsi maupun kabupaten. Akan tetapi jika ingin mengetahui data yang sangat detail seperti mengestimasi kerusakan bangunan akibat bencana dapat menggunakan data 
Ikonos (1 meter) dan quickbird (0,6 meter). Data ini dapat digunakan pada level lokal misalnya bagian suatu kota dan kecamatan.

\section{Penutup}

Dalam pengelolaan wilayah yang rawan bencana alam sangat memerlukan informasi dan data yang cepat dan akurat. Penginderaan jauh merupakan teknologi yang dapat diandalkan dalam menyediakan data-data tersebut. Akan tetapi pemanfaatan data dari penginderaan jauh ini harus disesuaikan dengan tingkat kerinciannya sehingga sesuai dengan kebutuhan aplikasinya.

Tingkat kerincian data dari penginderaan jauh sangat berkaitan dengan kemampuan resolusinya, terutama resolusi spasial. Resolusi spasial ini berkaitan dengan kemampuan sensor penginderaan jauh dalam merekam objek terkecil di permukaan bumi, semakin kecil angka resolusi spasialnya maka semakin detail informasi yang diperoleh. Misalnya citra Landsat TM memiliki resolusi spasial 30 meter, sedangkan citra Ikonos resolusi spasialnya 1 meter sehingga Ikononoslah yang lebih detail. Akan tetapi disini bukan masalah detailnya tetapi bergantung pada skala pemetaan yang akan digunakan. Jika skala pemetaannya dalam lingkup provinsi, citra yang paling cocok adalah Landsat, akan tetapi jika untuk pemetaan dalam kota maka citra yang paling cocok adalah Ikonos.

Dengan tersedianya data dan informasi geografis yang andal tentang semua wilayah Indonesia, baik dari tingkat nasional, provinsi, kabupaten/kota maupun lokal, pemanfaatan dan pengelolaan sumber daya alam dan lingkungan, perencaan wilayah, dan pengurangan risiko bencana di seluruh wilayah Indonesia akan semakin efektif dan efisien, sehingga data dan informasi geografis ini dapat digunakan oleh pemerintah baik pusat maupun daerah, maupun oleh pihak swasta dan masyarakat.

Oleh karena itu, kualitas sumber daya manusia yang menguasai teknologi penginderaan jauh dan sistem informasi geografis harus terus ditingkatkan mengingat wilayah Indonesia yang sangat luas dan belum semuanya terpetakan dengan baik dengan tingkatan skala yang lebih memadai.

\section{Daftar Pustaka}

Akil, S. 2010. Pengembangan Wilayah dan Penataan Ruang Di Indonesia: Tinjauan Teoritis dan Praktis. Makalah. Disajikan dalam Kuliah Terbuka Program Magister KAPET, Universitas Hasanuddin Makassar. Sumber http://www.penataanruang.net/taru/Makalah/PaperUNHAS-KAPET.pdf diakses pada 25 Februari 2010.

Arif, H. 2004. Resourcesat-1: Apakah Merupakan Generasi Penerus Landsat-7. BERITA INDERAJA VOL. III, No. 5, Juli 2004.

Hartono, 2009. Teknologi Penginderaan Jauh dan Perkembangannya. Makalah. Disampaikan pada Seminar Nasional dengan tema Peranan Penginderaan Jauh dalam Pembelajaran Geografi, kerjasama antara Fakultas Ilmu Sosial Universitas Negeri Semarang (UNNES) dengan Lembaga Penerbangan dan Antariksa Nasional (LAPAN), pada tanggal 29 Januari 2009.

Http://id.wikipedia.org/wiki/Program_Landsat diakses tanggal 19 Februari 2010. 
Http://salamspasial.blogspot.com/2008/05/sistem-satelit-landsat-7-etm diakses tanggal 19 Februari 2010.

Http://www.satimagingcorp.com/satellite-sensors/landsat.html diakses pada 24 Februari 2010.

Jensen, J.R. 2000. Remote Sensing of The Environment an Earth Resources Perspective. Pearson Education, Inc. University of South Carolina.

Martono, D. N. 2009. Aplikasi Data Penginderaan Jauh Dan Sistem Informasi Geografis Untuk Identifikasi Tingkat Keragaman Penggunaan Lahan. Seminar Nasional Aplikasi Teknologi Informasi 2009 (SNATI 2009) ISSN: 1907-5022. Yogyakarta, 20 Juni 2009.

Martono, D.N., Surlan, dan Sukmana, B.T. 2010. Aplikasi Data Penginderaan Jauh untuk Mendukung Perencanaan Tata Ruang di Indonesia. Inovasi online (http://io.ppi-jepang.org/article.php?id=168) diakses pada 25 Februari 2010.

Poniman, A. 2007. Dari Data Penginderaan Jauh Sampai Pengetahuan Geografis Sumberdaya Alam dan Lingkungan Hidup serta Kebencanaan. Makalah. Seminar Nasional Pembangunan Wilayah Berbasis Lingkungan di Indonesia, Dies UGM ke 58, IGEGAMA, KAGAMA, Fakultas Geografi UGM, IGI, Balai Senat UGM, Yogyakarta, 27 Oktober 2007.

Rahmat, A. 2010. Manajemen dan Mitigasi Bencana. Diakses pada 03 Maret 2010.

Thoha, A.S. 2008. Karakteristik Citra Satelit. Departemen Kehutanan Fakultas Pertanian Universitas Sumatera Utara. 